Vol. 07, No. 01; 2022

ISSN: $2456-8643$

\title{
COMPARATIVE STUDY OF THE DEMOGRAPHIC AND PHYLOGENETIC EVOLUTION OF SITOPHILUS ZEAMAIS IN 2 HUMID AND ARID ZONES OF CENTRAL AND WESTERN AFRICA
}

\author{
Ngagne Demba Sarra ${ }^{1}$, Ablaye Faye ${ }^{1}$ and Cheikh Thiaw ${ }^{2}$ \\ ${ }^{1}$ Faculty of sciences and Technology, Department of Animal Biology, University Cheikh Anta DIOP Dakar, Senegal \\ ${ }^{2}$ University of sine saloum ELHADJ IBRAHIMA NIASS sing-sing, BP 55, Kaolack, Senegal.
}

https://doi.org/10.35410/IJAEB.2022.5697

\begin{abstract}
In this article, it was a question of highlighting the models of demogenetic and phylogenetic evolution of Sitophilus zeamais, the main pest of maize stocks in Africa, in 2 humid and arid agroclimatic zones of West and Central Africa.
\end{abstract}

Methods: The insects were therefore collected from the same storage means, in four countries in the humid agro-climatic zone and five in the arid agro-climatic zone.

Results: The mitochondrial DNA of these insects was extracted and the cytochrome $b$ gene sequenced. The exploitation of these sequences has shown a demographic expansion in arid agro-climatic zones and a demographic stability in humid agro-climatic zones. The phylogenetic trees did not clearly show a genetic structure of the insect according to the two agro-climatic zones and a close phylogenetic relationship of the individuals of the two sets.

Conclusion: The demographic stability and the low genetic diversity of the population of the humid agro-climatic zone can be the signal of a bottleneck or the pledge of a population on the brink of extinction. While the population of the arid agro-climatic zone exhibiting a population expansion and a high genetic diversity may exhibit a greater resilience.

Keywords: Sitophilus zeamais, agro-climatic zone, cytochrome b, demographic expansion stability expansion.

\section{INTRODUCTION}

Today, Africa concentrates $60 \%$ of the extremely poor people of the planet, this rate is expected to increase to $90 \%$ by 2030 (World Bank,2019). The countries of West and Central Africa are the countries most affected by this scourge, where $30 \%$ of the population lives on less than $\$ 1.90$ a day (Oxfam international, 2019). This socio-economic situation has nevertheless given rise to some development policies, most of which are defined and set out in a general poverty reduction document, designed with a view to achieving the Millennium Development Goals of the World Bank and the International Monetary Fund. A significant part of these policies have been aimed at promoting the agriculture. But this sector is still struggling to achieve the objectives assigned to it in the fight against the scourge. The destruction of grain stocks, especially those of corn, one of the most important food and cash crops in Africa, is to blame for this failure. The chemical and biochemical solutions such as the use of pesticides and the use of plants hostile to the development of insects have been resorted to to eliminate the main pest of corn stocks, named Sitophilus zeamais. But their negative repercussions on the environment and living beings 
quickly highlighted their limits. Other studies aimed at getting to know the insect well, in order to better control it, have focused on its genetic distribution in West Africa (Ndong et al, 2014). This article also fits into this perspective : it aims to identify the demogenetic and phylogenetic models of Sitophilus zeamais in two agro-climatic zones of West and Central Africa. Taking into account the influence of the genotype on the adaptive phenotypes of the individual, the knowledge of the variability, of the genetic structuring of the insect (Ndiaye et al. 2018), but also of the demographic and phylogenetic evolution, can make it possible to understand comparatively the adaptability of Sitophilus zeamais in the two agro-climatic zones.

The insects were therefore collected in four countries in the humid agro-climatic zone (Cameroon, Central African Republic, Ghana and Ivory Coast) and five countries in the arid agro-climatic zone (Senegal, Niger, Mali, Burkina Faso, Guinea). The sequences of the Cyt.B gene of the individuals have been exploited in relation to parameters of demographic and phylogenetic evolution, by software for studying population genetics ((Arlequin, Bioédit, DNAsp, Mega ...)), in order to achieve the goals we have set for ourselves.

\section{MATERIAL AND METHODS}

\subsection{Sampling}

\subsubsection{Sampling localities}

The individuals of Sitophilus zeamais were sampled in 9 countries from 2 agro-climatic zones (ACZ) of West and Central Africa. These are Senegal, Mali, Burkina Faso, Guinea Conakry and Niger from the arid zone. The other countries in the wetland where the harvest was made are Ghana, Côte d'Ivoire, Central Africa and Cameroon. Figures I and II summarize the sampling.

Figure I: Sampling country in a Humid Agroclimatic Zone

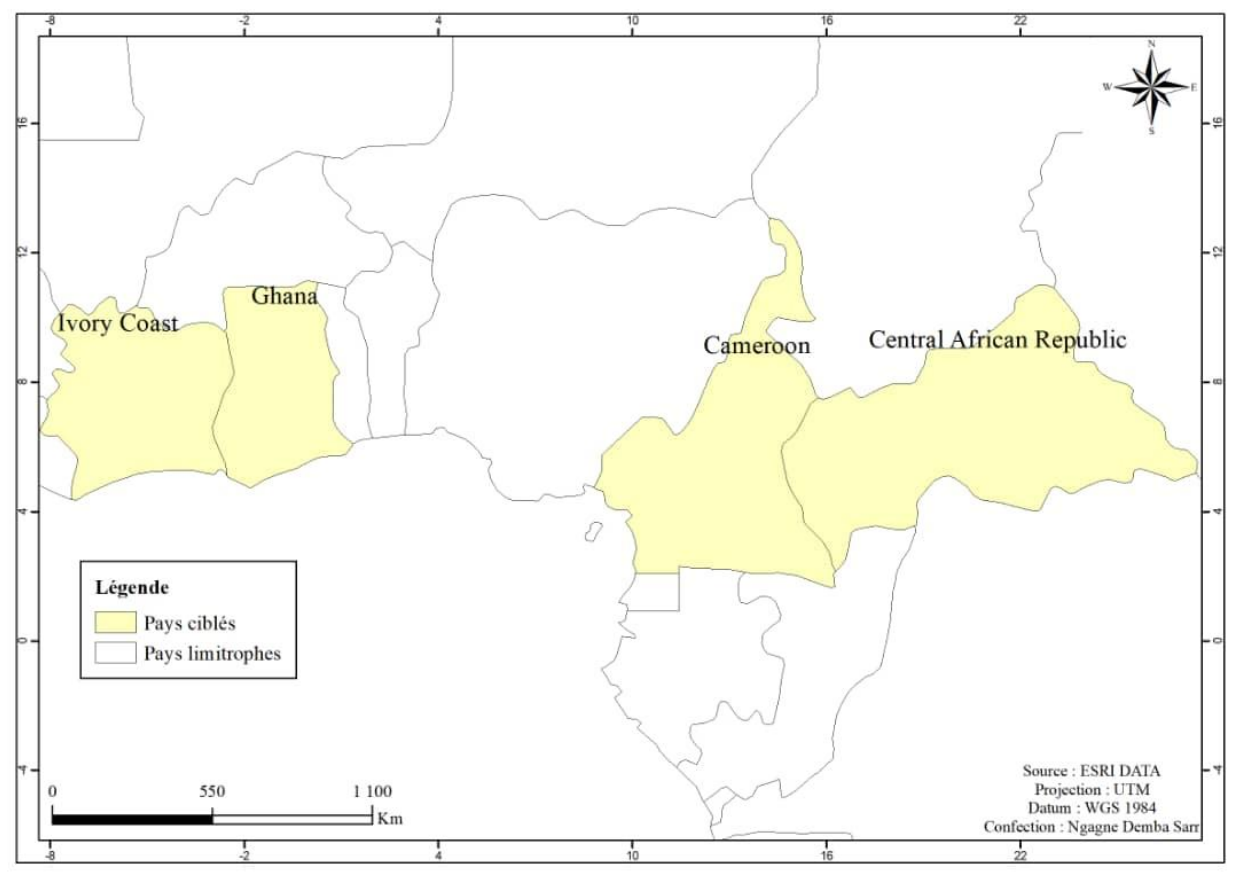


Figure II : Sampling country in Arid Agroclimatic Zone

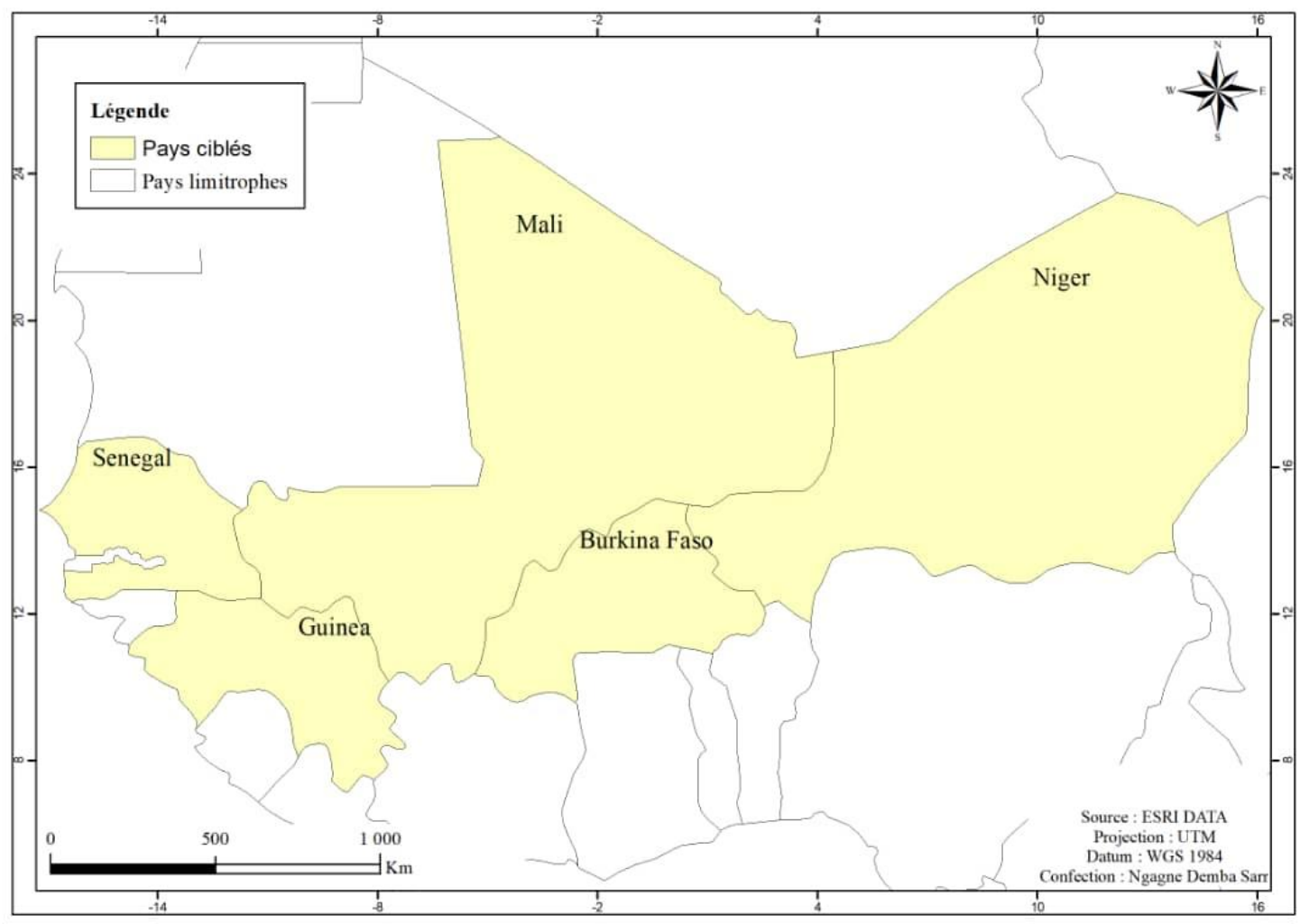

\subsection{Harvesting individuals}

The collection of infested corn samples in the different agroclimaic zones (ACZ) made it possible to isolate the individuals of Sitophilus zeamais for each zone. It was carried out in the fields, in storage facilities where the grains are very vulnerable to infestation, but also in places of marketing where the chance of encountering infested maize from the various ACZ is high.

After the isolation, the individuals from each ACZ are placed in tubes containing $96 \%$ alcohol and then transported to the laboratory for genetic study. Each sample is identified by a code: the first 2 letters designate the binomial name of the species ( $\mathrm{S}$ for Sitophilus and $\mathrm{z}$ for zeamais), the 2 letters which follow indicate the country of origin (example: SzSn, with $\mathrm{S}=$ Sitophilus, $\mathrm{z}=$ zeamais, $\mathrm{Sn}=$ Senegal, $\mathrm{SzBf}$, with $\mathrm{S}=$ Sitophilus, $\mathrm{z}=$ zeamais, $\mathrm{Bf}=$ Burkina Faso.

\subsection{Molecular method of analysis}

\subsubsection{DNA extraction}

The extraction is the technique of releasing DNA from the cell. It involves the individualization of cells (digestion) and the destruction of their plasma and nuclear membranes (lysis).

The digestion of the cells consisted of placing their legs and prothorax in tubes containing ATL buffer and proteinases K. After incubation, the tubes were centrifuged to separate the supernatant from the cell debris.

To destroy the cell membranes, first some cell lysis buffer (LA) was added, then some ethanol (96\%) after incubation, in the tubes. Then the tubes are crossed in columns with a silica 
membrane. Finally, the centrifugation of the tubes made it possible to retain the DNA on the siliceous membranes of the columns because it was negatively charged.

\subsubsection{DNA purification}

The DNA of the tubes was purified by adding 2 buffers AW1 and AW2 to each column. After centrifuging of the tubes and precipitating the DNA from the bottom, the buffers and contaminants are discarded. The columns are then placed in other tubes in which buffer AE has been added to detach the DNA. The DNA is thus removed and stored at $-20^{\circ} \mathrm{C}$.

II.2.3. PCR of the mitochondrial Cytochrome B gene

PCR of the mitochondrial Cyt.B gene was performed by 2 primers CB1 (5'TATGTACTACCATGAGGACAAATATC-3 ') and (ATTACACCTCCTAATTTATTAGGAAT-3'). For each sample (tube), the amplification was made from a total volume of $25 \mu 1$, including a mixed volume of $23 \mu 1$ and a volume of $2 \mu 1$ of DNA extract. The mixed volume was constituted by: $18.3 \mu$ l of milli water, $2.5 \mu 1$ of $10 \mathrm{X}$ buffer, $1 \mu \mathrm{l}$ of additional $\mathrm{Mgcl} 2,0.5 \mu \mathrm{l}$ of Dntp, $0.25 \mu \mathrm{l}$ of each primer and $0.2 \mu \mathrm{l}$ of Taq polymerase.

The conditions under which the PCR was performed are as follows:

-The DNA strands were first separated at a temperature of $94^{\circ} \mathrm{C}$ for 3 minutes. This first denaturation was followed by 35 denaturation cycles of 1 minute at the same temperature.

-The synthesis of complementary strands (elongation) was carried out at $72^{\circ} \mathrm{C}$. for 10 minutes. After amplification, the fragments are sent to a South Korean company for sequencing.

II.2.4. Bioinformatics analyzes

The sequences were corrected and aligned by the Clustal software installed in the Bioedit version 7.2.5 program (Hall, 1999).

The demographic history of the populations sampled in the different agro-climatic zones was apprehended from a "mismatch distribution" analysis of the populations, correlated with the evaluation of the demographic tests of $\mathrm{D}$ of tajima, of $\mathrm{D} *$ and $\mathrm{F} *$ of $\mathrm{Fu}$ and $\mathrm{Li}(\mathrm{Fu}$ and $\mathrm{Li}$, 1999), of $\mathrm{Fs}$ of $\mathrm{Fu}(\mathrm{Fu}, 1997)$, of $\mathrm{R} 2$ of Ramos and $\mathrm{H}$ of Fay and $\mathrm{Wu}$. This analysis is accredited by the demographic indices SSD (sum of the squares of deviations) and RAG, calculated between observed and expected distributions, by the Arlequin 3.5.13 software (Excoffier and Lischer, 2010). The values of $\mathrm{D}$ of tajima, of $\mathrm{Fs}$ of $\mathrm{Fu}$ and $\mathrm{D} *$ and $\mathrm{F} *$ of $\mathrm{Fu}$ and $\mathrm{Li}$ were calculated by the software Arlequin 3.5.13. While those of the R2 of Ramos and H of Fay and Wu were calculated by the DNAsp software.

The phylogenetic reconstruction makes it possible to clarify the kinship relationships existing between haplotypes identified in the different agroecological zones. Thus in our study, we built a phylogenetic tree one according to the Bayesian approach, from the software Mr Bayes version 3.12 (2007). The exploitation of the tree will make it possible to verify the consistency of the interpretation of the phylogeny of populations.

\section{RESULTS AND DISCUSSION}

\subsection{Results}

The values of $\mathrm{D}$ of Tajima and $\mathrm{H}$ of Fay and $\mathrm{Wu}$ for the humid agro-climatic zone are negative and not significant. The values of R2 and Fs of Fu for this region are positive and not significant. The values of the other demographic parameters are positive and therefore insignificant. At the same time, in an arid agro-climatic zone, the values of D of Tajima and Fs of Fu are significantly 
Vol. 07, No. 01; 2022

ISSN: $2456-8643$

negative. The value of $\mathrm{H}$ of Fay and $\mathrm{Wu}$ is negative and not significant while that of $\mathrm{R} 2$ is positive and negative.

Table I: Demo-genetic tests in the 2 agro-climatic zones

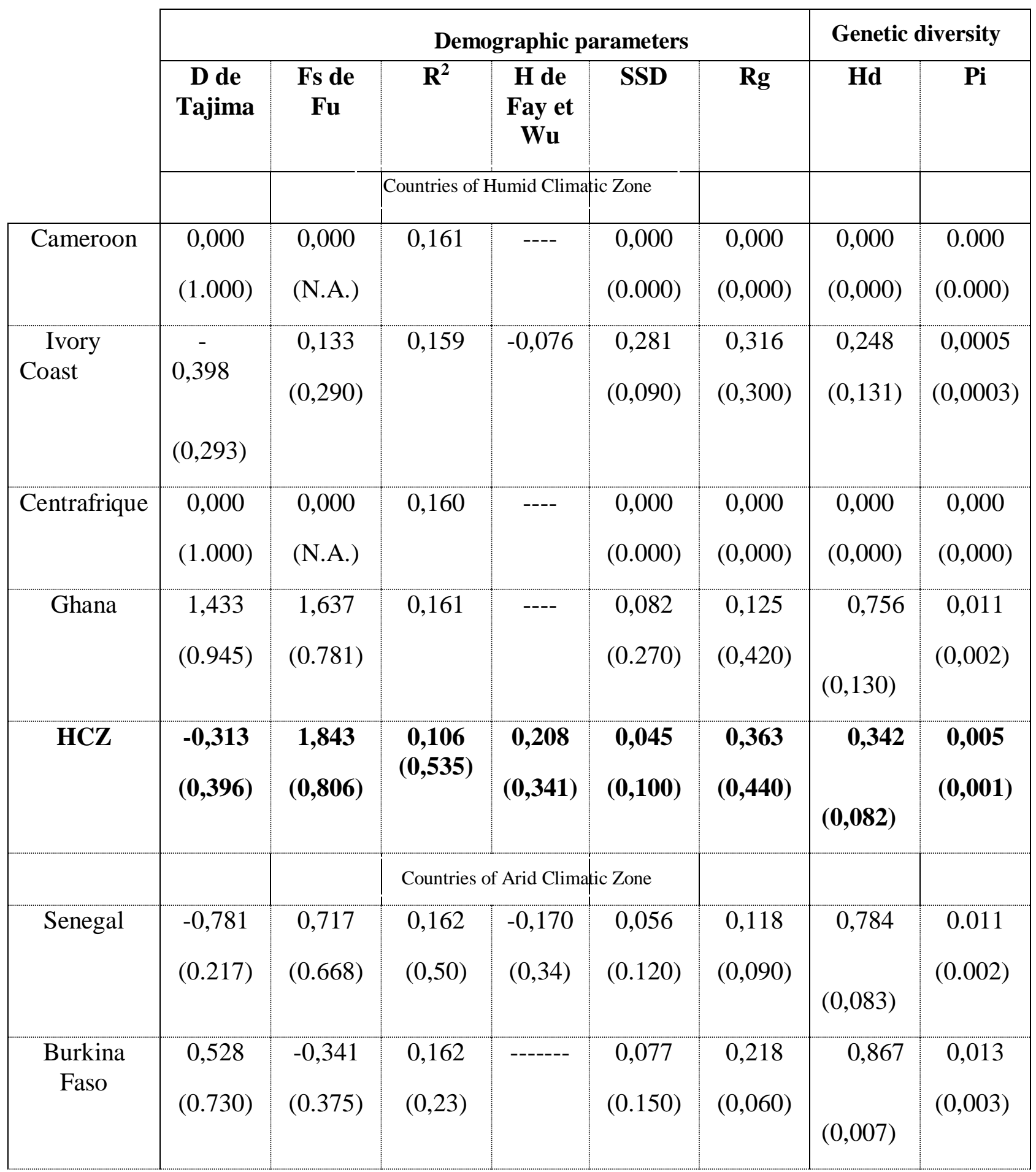


International Journal of Agriculture, Environment and Bioresearch

Vol. 07, No. 01; 2022

ISSN: $2456-8643$

\begin{tabular}{|c|c|c|c|c|c|c|c|c|}
\hline Mali & $\begin{array}{c}0,000 \\
(1,000)\end{array}$ & $\begin{array}{c}0,000 \\
(1,000)\end{array}$ & -------- & -------- & $\begin{array}{c}0,000 \\
(0,000)\end{array}$ & $\begin{array}{c}0,000 \\
(0,000)\end{array}$ & $\begin{array}{r}0,000 \\
(0,000)\end{array}$ & $\begin{array}{c}0,000 \\
(0,000)\end{array}$ \\
\hline Niger & $\begin{array}{l}-0,418 \\
(0.341)\end{array}$ & $\begin{array}{c}1,232 \\
(0.720)\end{array}$ & $\begin{array}{c}0,161 \\
(0,53)\end{array}$ & $\begin{array}{c}0,041 \\
(0,33)\end{array}$ & $\begin{array}{c}0,049 \\
(0.500)\end{array}$ & $\begin{array}{c}0,080 \\
(0,530)\end{array}$ & $\begin{array}{r}0,844 \\
(0,103)\end{array}$ & $\begin{array}{c}0,011 \\
(0,002)\end{array}$ \\
\hline Guinea & $\begin{array}{l}-0,842 \\
(0.215)\end{array}$ & $\begin{array}{c}0,223 \\
(0.552)\end{array}$ & $\begin{array}{c}0,161 \\
(0,53)\end{array}$ & $\begin{array}{l}-0,007 \\
(0,32)\end{array}$ & $\begin{array}{c}0,037 \\
(0.180)\end{array}$ & $\begin{array}{c}0,134 \\
(0,530)\end{array}$ & $\begin{array}{r}0,711 \\
(0,117)\end{array}$ & $\begin{array}{c}0,003 \\
(0,001)\end{array}$ \\
\hline ACZ & $\begin{array}{r}-1,8350 \\
(0,011)\end{array}$ & $\begin{array}{l}-5,7384 \\
(0,034)\end{array}$ & $\begin{array}{c}\mathbf{0 , 1 0 0} \\
(\mathbf{0 , 5 1 7})\end{array}$ & $\begin{array}{l}-0,057 \\
(0,315)\end{array}$ & $\begin{array}{l}0,7493 \\
(0,000)\end{array}$ & $\begin{array}{r}0,04557 \\
(0,100)\end{array}$ & $\begin{array}{r}\mathbf{0 , 8 2 0} \\
(\mathbf{0 , 0 4 5 )}\end{array}$ & $\begin{array}{c}0,011 \\
(0,002)\end{array}$ \\
\hline $\begin{array}{l}\text { Global } \\
\text { population }\end{array}$ & $\begin{array}{c}- \\
1,07444 \\
(0,2030)\end{array}$ & $\begin{array}{c}- \\
1,94760 \\
(0,4200)\end{array}$ & $\begin{array}{c}0,1089 \\
(0,5600)\end{array}$ & & $\begin{array}{l}0,39741 \\
(0,0500)\end{array}$ & $\begin{array}{c}0,1953 \\
(0,7200)\end{array}$ & $\begin{array}{c}0,6448 \\
(0,1232)\end{array}$ & $\begin{array}{l}0,00895 \\
(0,0010)\end{array}$ \\
\hline
\end{tabular}

The Mismatch curve of the global Sitophilus zeamais population in West and Central Africa is multimodal. The values of the demographic indices are significant for the SSD and not for the $\mathrm{Rg}$. The haplotypic diversity of the total population is high while the nucleotide diversity is low. The arid zone's Mismatch distribution curve is multimodal, that of the wetland is also, but with only two peaks. The values of SSD and Rg are not significant in a humid area. In the Sahelian zone, the value of Rg is not significant, on the other hand that of SSD is significant. The arid agro-climatic zone is characterized by high genetic diversity compared to the humid agroclimatic zone. 
Figure III : Mismatch distribution curve of the 2 agro-climatic zones
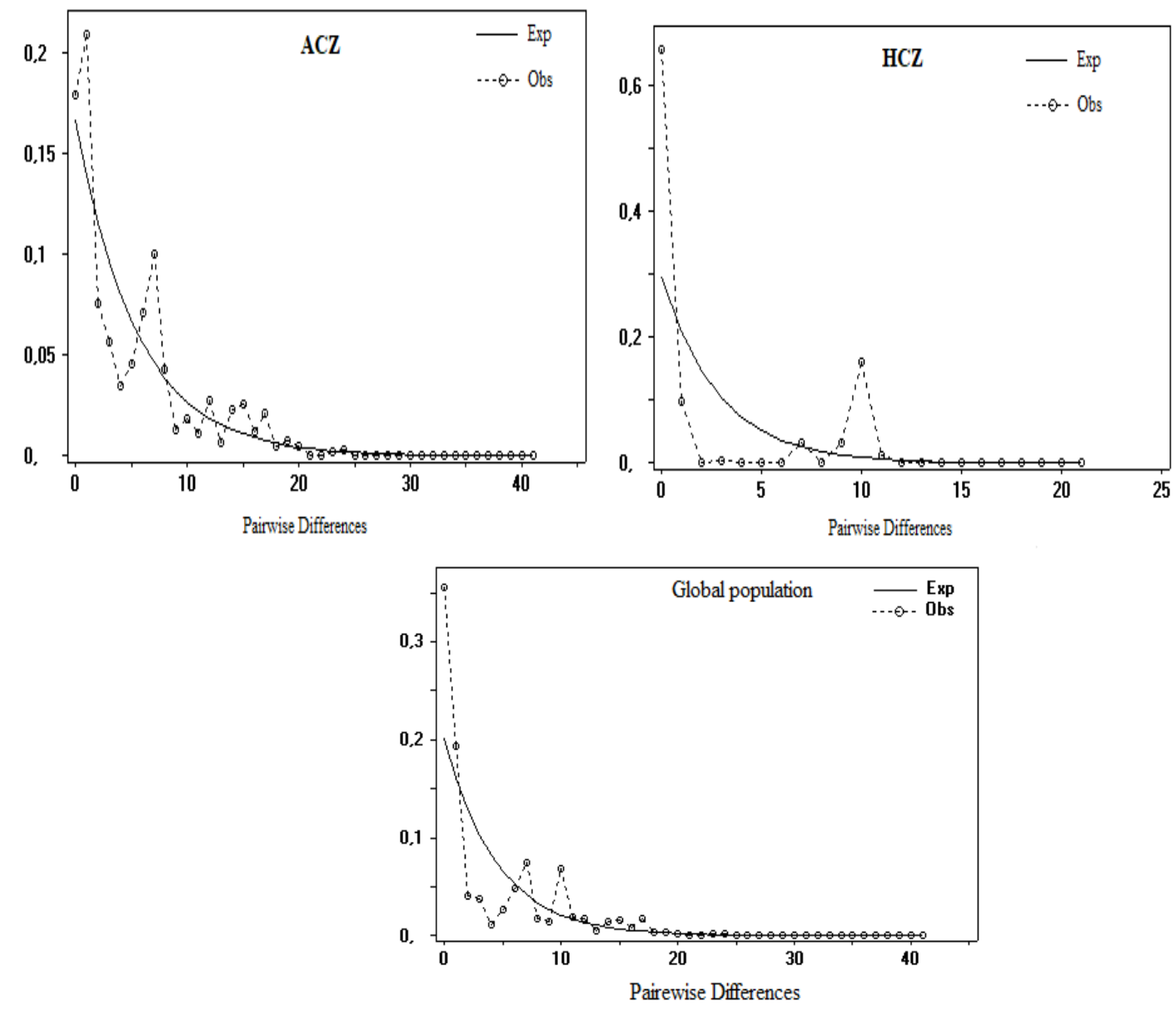

The phylogenetic tree according to the Bayesian approach highlighted 5 groups, including one group made up of unresolved haplotypes belonging to the 2 zones. The other 4 clades are strongly supported by posterior probability values : a group formed of haplotypes from Senegal and the Republic of Guinea, a group subservient to Ghana, a third group of haplotypes from Niger and Burkina Faso and finally a final group consisting of haplotypes from the humid and arid zone.

Figure IV : Phylogenetic tree according to the Bayesian approach 
Vol. 07, No. 01; 2022

ISSN: $2456-8643$

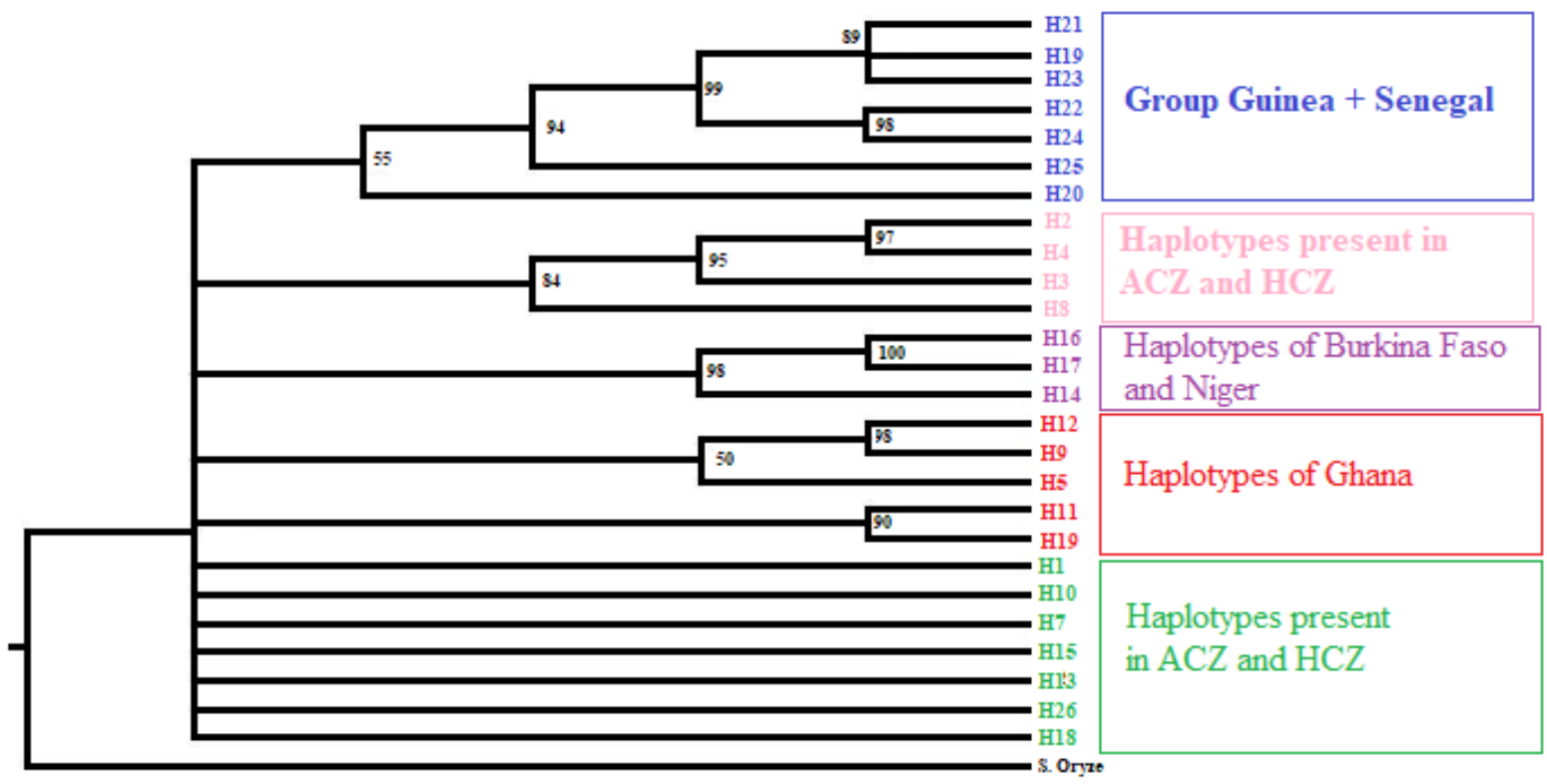

\subsection{Discussion}

The aim of this study was on the one hand to compare the models of demographic evolution, the types of selection of the populations of Sitophilus zeamais and on the other hand to apprehend the degree of relatedness of the individuals of this insect in two zones arid and humid agroclimatic of Central and West Africa. In this perspective, some parameters of demographic expansion, of phylogenetics and demo-genetics have been calculated and exploited. The multimodal distribution of mismatch indicates a stability of the overall Sitophilus zeamais population in West and Central Africa because a stationary population would result in a multimodal curve, while a population having undergone population expansion would result in a unimodal curve. (Roger \& Harpending, 1992; Harpending, 1994; Marjoram \& Donnelly, 1994; Schneider \& Excoffier, 1999). However, this stability is contrasted by the significance of the value of SSD and the insignificance of that of $\mathrm{Rg}$. On the other hand, the high haplotypic diversity and low nucleotide diversity suggest rather a population at the beginning of demographic expansion. This hypothesis is confirmed by the negative values of $\mathrm{D}$ of Tajima and Fs of Fu. The population expansion could come from a bottleneck. Indeed, a high haplotypic diversity and low nucleotide diversity can be the result of a rapid population growth from an ancestral population with low numbers, because having undergone a bottleneck and for which there was not enough time elapsed to find a high diversity between the haplotypes (Avise, 2000 ; Grant and Bowen, 1998).

This type of demographic expansion of a population following a bottleneck was highlighted by a study by Sézonlin et al in 2006, on a cereal stalk borer (Busseola Fusca) in West Africa, one of the agro-climatic zones that are discussed in this study. The demographic expansion of Sitophilus zeamais in West and Central Africa could occur after the glacial maximum, which would have drastically reduced the population of the insect, because studies have had to reveal colonizations of species of new territories after this. ice age (Hewitt, 2000). The population of the arid agroclimatic zone of Sitophilus zeamais has experienced a demographic stability according to the multimodality of the Mismatch distribution. However, this pattern of demographic change is not 
clearly confirmed insofar as the value of SSD is significant while that of $\mathrm{Rg}$ is not. The significantly negative values of $\mathrm{D}$ from Tajima and Fs from $\mathrm{Fu}$ on the one hand, and the high haplotypic and low nucleotide diversity on the other hand, are in favor of population expansion. The negative value of $\mathrm{H}$ of Fay and $\mathrm{Wu}$ indicates the presence of rare variants in this population of the arid zone which would thus be in demographic expansion. The demographic expansion of the Sitophilus Zeamais population in the Sahelian zone may be the result of a change in climatic conditions. Indeed after the ice age, the forestation of the area, the development and intensification of agriculture made the ecological conditions favorable to the point of causing the insect to flourish.

The humid agro-climatic zone is characterized by a bimodal Mismatch curve, a sign of a demographic stability. The insignificance of the values of SSD and Rg supports this hypothesis. However, the low genetic diversity of this population is more indicative of the advent of a bottleneck. Indeed, a haplotypic and nucleotide diversity on mitochondrial DNA can be a signal of a severe and prolonged bottleneck (Salducci et al. 2004). So instead of a demographic stability, the bimodality of the wetland population could reflect two past booming events that led to the presence of different halogroups. The predominance in a humid zone of two clades (Central African Republic and Cameroon) made up of strongly divergent haplotypes supports this hypothesis. This divergence between haplotypes validates a long separation of populations allowing the loss of several haplotypes by genetic drift. Thus the populations of Cameroon and Central Africa would have undergone a recent demographic bottleneck or experienced a founding effect by a small number of lineages (Grant and Bowen, 1998). The thesis of a bottleneck of these populations is supported by the positive value of $\mathrm{H}$ de Fay and Wu.

The phylogenetic tree highlighted 5 strongly supported clades: A haplogroup made up of insects native to Senegal and Guinea. The geographical proximity, the exchange of cereals between these countries can be at the origin of this sharing of haplotypes. Indeed, the transfer of grains from one area to another may be accompanied by the transfer of larvae, egg-laying cocoons or even adults capable of flourishing in an area which has not yet been infested (Kébé, 2013; Ndiaye, 2014). Two clades each formed from individuals from Burkina Faso and Niger and finally two haplogroups from Ghana and Niger respectively. The five clades would diverge in the Pleistocene according to Bayesian molecular dating, a period characterized by an unstable climate in an arid agro-climatic zone with alternating hot and humid, cold and dry seasons (Wagner, 2002). These large variations have influenced the genetic diversity of many species and communities (Hewitt, 2000), including the stem borer, Busseola Fusca, whose genetic structure is explained by these events of the same period (Sezonlin et al. 2006).

\section{REFERENCES}

Avise, JC., Arnold, J., Ball, RM., Bermingham, E., Lamb, T., Neigel, JE., Reeb, CA., Saunders, NC. (1987). Intraspecific phylogeography : the mitochondrial DNA bridge between population genetics and systematics.

Avise, JC. (1994). Molecular Markers, Natural History, and Evolution. Chapman and Hall, (New York). 511p.

Bossart, JL., Prowell, DP. (1998). Genetic estimates of population structure and gene flow : limitation, lessons, and new directions. Trends Ecol. Evol. 13, 202e206. 
Delobel, B., Grenier, AM. (1993). Effect of non-cereal food on cereal weevils and tamarind pod weevil (Coleoptera : Curculionidae). J. Stored Prod. Res., (29) : 7-14.

Delobel, A., Tran, M. (1993). Les coléoptères des denrées alimentaires entreposées dans les régions chaudes, Paris, éditions ORSTOM. 425 p.

Delobel, A. (1995). The shift of Caryedon serratus Ol. From wild Caesalpiniaceae to groundnuts took place in West Africa (Coleoptera : Bruchidae). Journal of Stored Products Research, 31 (I) : 101-102.

Moyal, P. (1994). Maize Cob-borer abundance and influence on yield in côte d'ivoire. International Journal of Tropical Insect Science, 15(4-5), 469-478.doi $: 10.1017 /$ S1742758400015836.

Moyal, P. (1993). Maize crop Intensification and borer attacks in the Ivory Coast. Yields. Soil Boita, Nutvient cycling, and Farming Systems, CRC Press, Boca Raton, FL, chap. 22, P.254.

Ndong, A. (2015). Caractérisation génétique de Sitophilus spp., ravageur des stocks de maïs et essais d'éradication du virus de la mosaïque du manioc Manihot esculenta par la culture de tissus in vitro. Thèse de Doctorat. Université Cheikh Anta Diop de Dakar (Sénégal), 314p.

Reed, DH., Frankham, R. (2003). Correlation between Fitness and Genetic Diversity. Conservation Biology, 17 : 230-237.doi :10.1046/j.1523-1739.2003.01236. X.

Sarr, AGRJ., Dia, CAKM., Ndiaye, MR., Sembène, M. (2016). Genetic Structure of Two Sitophilus (Coleoptera, Curculionidae) Species According to Storage Infrastructures and Agroecological Areas. University Cheikh Anta DIOP of Dakar. International Journal of Science and Advanced Technology (ISSN 2221-8386) Vol. 6 (4) : 1-11.

Sembène, M. (2000). Variabilité de l'Espaceur Interne Transcrit (ITS) de l'ADN ribosomique et polymorphisme des locus microsatellites chez le bruche Caryedon serratus (Olivier, 1790) : différenciation en races hôtes et infestation de l'arachide au Sénégal. Thèse de Doctorat d'Etat es Sciences Université Cheikh Anta Diop de Dakar (Sénégal), 180p.

Sembène, M., Kébé, K., Delobel, A. (2012). Effet structurant de la plante hôte chez le bruche de l'arachide, Caryedon serratus (Olivier, 1790) (Coleoptera : Bruchidae). Biotechnologie Agronomie Societe Environment, 16 (1) : 3-11.

Sembène, M. (2012b). De la naissance des concepts à la génétique évolutive des populations. Cours de master II de spécialité « Génétique des populations ». Université Cheikh Anta DIOP de Dakar.

Sezonlin, M., Dupas, S., Moyal, P., Calatayud, PA., Giffard, I., Faure, N., Silvain, JF. (2006). Phylogeography and population genetics of the maize stalk borer Busseola fusca (Lepidoptera, Noctuidae) in sub-Saharan Africa. Mol. Ecol. 15, 407e420.

Tamgno, BR., Ngamo T. (2018). Potentialisation de l'efficacité insecticide des poudres de feuilles ou amandes de neemier Azadirachta indica A. juss par formulation avec la cendre de tiges de mil contre Sitophilus zeamais Motsch. et Sitophilus oryzae L( coleoptera : curculionidae). African Journal of Food Agriculture Nutrition and Development.18(1) : 1325413270. Doi : 10.18697/ajfand.81.17095. 